\title{
Kastamonu İli Turizm Potansiyeli ve İnanç Turizminin Şehirdeki Yeri ve Önemi
}

\author{
Oğuz ÇAM \\ Kastamonu Üniversitesi Sosyal Bilimler Enstitüsü \\ oguzcam911@gmail.com \\ https://orcid.org/0000-0003-3222-3367 \\ Hakkı ÇILGINOĞLU \\ Kastamonu Üniversitesi Turizm Fakültesi \\ hcilginoglu@ kastamonu.edu.tr \\ https://orcid.org/0000-0002-6787-3397 \\ https://doi.org/10.37847/tdtad.740123
}

Özet

Araştırmanın amacı unutulmaya yüz tutmuş değerleri yaşatmak, turizm potansiyelini değerlendirmek, avantajlarını ve dezavantajlarını ölçmek, Kastamonu şehrindeki turizmin önündeki sorunları belirleyip çözüm önerileri sunmak ve son olarak da turizm bilinci geliştirmektir. Bu araştırmada sosyal bilimlerde araştırma yöntemlerinden olan nitel araştırma metodu kullanılmıştır. $\mathrm{Bu}$ araştırmanın veri toplama aracı ve analizi görüşme formu tekniğidir. Kastamonu'da inanç turizmi denilince akla ilk olarak Hz. Pir Şeyh Şaban-1 Veli gelmektedir. Kastamonu'da kış, inanç, kültür, gastronomi, ormancılık ve tabiat turizmi en çok bilinen turizm çeşitleri arasındadır. Kastamonu şehrinde az bilinen turizm çeşitleri arasında ise eko turizm, dağ/doğa yürüyüşü (trekking), doğa, kongre, kitle, av, deniz, sağllk, çiftlik ve macera turizmi gelmektedir. Sonuç olarak; Kendine has doğal, tarihi ve kültürel çekiciliklerinin olması, bunların muhafaza edilmesiyle Kastamonu diğer illerle kıyaslandığında bir farkındalık ortaya koymaktadır. Kastamonu ilinde birçok turizm türü uygulanabilmektedir; Kültür turizmi, kongre turizmi, ormancılık ve tabiat turizmi, inanç turizmi, deniz turizmi, kış turizmi ve kitle turizmi örnek gösterilebilmektedir. Evliyalar şehri olarak da anılan Kastamonu yaklaşık 17 bin evliyanın yaşadığı bir yer olarak dikkat çekmektedir.

Anahtar Kelimeler: İnanç turizmi, Kastamonu, İnanç Destinasyonları, Şeyh Şaban-1 Veli, Kültürel Değerler.

\section{Kastamonu Province Tourism Potential and the Importance of Faith Tourism in the City}

\begin{abstract}
The aim of the research is to keep the values that have been forgotten, to evaluate the potential of tourism, to measure their advantages and disadvantages, to determine the problems in front of tourism in Kastamonu city, to offer solutions and finally to develop tourism awareness. In this research, qualitative research method, one of the research methods in social sciences, was used. The data collection tool and analysis of this research is the interview form technique. When it comes to belief tourism in Kastamonu, Hz. Pir Sheikh Saban-i Veli is coming. Winter, belief, culture, gastronomy, forestry and nature tourism are among the most known tourism types in Kastamonu. Among the lesser known types of tourism in the city of Kastamonu are eco tourism, mountain / trekking, nature, congress, mass, hunting, sea, health, farm and adventure tourism. As a result; The fact that they have their own natural, historical and cultural attractions reveals an awareness compared to other provinces with their conservation. Many tourism types can be implemented in Kastamonu province; Cultural tourism, congress tourism, forestry and nature tourism, faith tourism, sea tourism, winter tourism and mass tourism can be exemplified. Kastamonu, also known as the city of awliya, draws attention as a place where approximately 17 thousand awliya live.
\end{abstract}

Keywords: Faith Tourism, Kastamonu, Faith Destinations, Sheikh Şaban-1 Veli, Cultural Values.

\section{Giriş}

Kastamonu İli Türkiye'nin en önemli tarih ve kültür merkezlerinden bir tanesidir. İçerisinde barındırdığı pek çok müze, han, hamam, kervansaray, cami, mescit, kale, kule, mesire alanları,

July-2020 Vol:5 No:1 International Journal of Turkic World Tourism Studies 
doğal, tarihi ve kültürel açıdan önemli sayılacak mekânlar ile adeta insanları kendisine büyülemektedir. 2018 y1lında Türk Dünyası Kültür Başkenti olmuş, bu gelişmeler ile marka farkındalığı ve imaj profilinde olumlu etkiler yaratmıştır. Reklam ve tanıtım etkinlikleriyle dünya çapında bir ilgi görmüştür. Yaşanmayan ve yaşatılmayan bir kültür unutulmaya mahkûm olacaktır. Kastamonu yöresi insanlarımızın sıcakkanlı ve samimi oluşu gezginleri o bölgeyi tekrardan ziyaret etmesine ön ayak olmaktadır. Kastamonu birçok medeniyete de ev sahipliği yapmıştır. Zaman içinde üzerinde bulunulan bu topraklar, bu doğrultuda şekillenmiştir. Kastamonu ilinde birçok turizm türleri de uygulanabilmektedir; Kültür turizmi, kongre turizmi, ormancılık ve tabiat turizmi, inanç turizmi, deniz turizmi (deniz, kum, güneş üçlüsü dikkat çekici etkiye sahip), kış turizmi (Ilgaz ve Küre dağları milli parkları önemli sayılabilen mekânlardır) ve kitle turizmi örnek gösterilebilmektedir.

Evliyalar şehri olarak da anılan Kastamonu Yaklaşık 17 bin evliyanın yaşadığı bir yer olarak dikkat çekmektedir. Anadolu'nun dört manevi direğinden bir olarak tanınan Hz. Pir Şeyh Şaban-1 Veli ve külliyesi (Anadolu'nun diğer üç manevi direği ise; Mevlana Celaleddin Rumi, Hacı Bektaş-1 Veli ve Hacı Bayram-1 Veli'dir) inanç turizmi bağlamında çok büyük ilgi çekmektedir. Kendisi Kastamonuludur ve hep insanlığa ve hayata dair faydalı olmak ana prensibidir. Gerek şeriata bağlılığı, insanlık karakteri, hayat felsefesi, Allah'a bağl1lığı ve Kur'an-1 Kerim'deki emir ve yasakları hayatında hep uygulama içerisinde olması, peygamber efendimizin sünnetlerini yerine getirmeye çalışmasıyla eşsiz, benzersiz bir insan olması yüce Allah'tan bizlere verilmiş ilahi bir hediyedir.

Kastamonu turizmde önemli bir işleve ve potansiyele sahip bir ildir. Doğa ve tabiatla iç içedir. Yeşilin maviyle buluştuğu olağanüstü bir konuma sahiptir. Şehirdeki altyapı ve üstyapı gelişim içerisindedir. Yaklaşık 17 bin evliyanın yaşamış olduğu bir şehir olarak dikkat çekmektedir. Turizm 12 aya yayılmaya çalışılmakta, turizmde bilinçlendirme çalışmalarına önem verilmektedir. Doğal ve tarihi güzellikleri ile turistleri kendine hayran bırakmaktadır. Camileri, medreseleri, hanları, hamamları, kervansarayları, kalesi, saat kulesi, milli parkları, gölleri, çeşmeleri ve mesire alanları ile turistleri kendisine hayran bırakmaktadır. Şehir halkı çok hoşgörülü, sıcak ve cana yakın insanlardır. Kültürel etkileşim görülmektedir. Anlayışı ve hoşgörülü bir ortam bölgeye ve insanlara hâkim olmaktadır.

Kastamonu ili Karadeniz Bölgesinin batı kesiminde bulunmakta ve birçok turizm türü için önemli bir yerdir. Kitle turizmi, deniz turizmi, yaz turizmi, kongre turizmi, kış turizmi, inanç turizmi, sağlık turizmi, kayak turizmi gibi turizm çeşitlerinde faaliyet gösterilmektedir. Özellikle 2018'de Kastamonu çok önemli gelişme göstermiştir. Bu yılda Türk Dünyası Kültür Başkenti seçilmiştir. Reklam ve tanıtım etkinlikleri çok rağbet görmüştür. Şehir markasında olumlu izler bırakmıştır. Böylelikle şehir ve ülke ekonomisine katkı sağlamış, tanınırlığı artmış, ulusal ve uluslararası kanallarda çok büyük yankı bulması sağlanmıştır.

\section{Literatür İncelemesi}

\section{İnanç Kavramı}

TDK tarafindan yapılan tarife göreyse, bir mütalaaya yürekten tabi olma, herhangi kimseye duyulan inanma ve güven duygusu manasında olup yaratıcıya, dine itikat manalarını ifade etmektedir. Toplumsal ve fert olarak hayatımızda oldukça etkili bir rol üstlenen inanç, fertlerin sosyal hayatında ve kendi iç dünyasındaki dengeyi oluşturmada son derece mühim bir fonksiyon üstlenmektedir (Karacoşkun, 2004: 25).

\section{Turizm Kavramı}

Turizm, devamlı bir şekilde ikamet edilen mekân dışına, bir günden az olmamak ya da en az bir gün boyunca konaklama yapılması koşulu ile iş, merak, zevk, eğlence, dinlenme, spor, din, akraba ziyaretleri, seminer ve kongrelere katılım sağlama gibi gereksinimlerin ortadan 
kaldırılması sebebiyle toplu ya da bireysel olarak yapılan seyahatlerin bütünü olarak isimlendirilmektedir (Küçük, 2010: 755).

Uluslararası Bilimsel Turizm Uzmanları Birliği (AEIST)'ne göre turizmin anlamı; ' 'kişilerin devam hayatını sürdürdükleri, geçimini sağladıkları ve bütün zaman ki mevcut gereksinimlerini yerine getirdikleri mekânlar dişında seyahatleri ve buradaki yerlerde, bilhassa turizm işletmesinin oluşturduğu hizmet ve ürünleri talep ederek kısa vadeli konaklamalarından ortaya çıkan ilişkiler ve durumların tümü', olarak tarif edilmektedir (Kozak, Kozak ve Kozak, 2010: 3).

\section{Destinasyon Kavramı}

Özdemir (2007: 1) destinasyonu; kuruluşunda barındırdığı değişik türdeki turizm kaynağ1 yardımıyla turistler için bir çekici kaynağı içeren ve sıkı şekilde turist ziyaretine ev sahipliği eden, kuruluş ve kurumların temin ettiği dolaylı veya doğrudan turizm ihtimamlarının toplamından meydana gelen komplike bir eser olarak açıklamaktadır.

\section{İnanç Turizmi}

İnsanla başlayan ve bununla beraber var olan dinler ve dinlerin yayılması amaciyla da dini gayeli seyahatler hep zaman olmuştur. Dini gezilerin meydana gelmesine sebep olan din büyüklerinin ve peygamberlerin yaşadıkları mekânlar mukaddes yerler olmuştur. İnsan hem dini inançları icabı hem de mukaddes mekânlarda yaşamış olan din yetişkinlerinin mezarlarını ziyaret etmekte ve bu seyahatlerle beraber din yetişkinlerinin hatıralarını devam ettirmektedir. Bilhassa bu seyahatlerin arka yüzünde olan en mühim şeyse dini hislerin yeniden açı̆̆a çıkmasını ve bu nedenle de insanlar ile kültür açısından ticari temasların ortaya çıkmasına destek olmaktadır (Kaynak ve Sezgin, 2008: 35).

\section{Dünyadaki İnanç Destinasyonları}

İslamiyet'te mukaddes yerler Medine ve Mekke; Hristiyanlıktaysa Roma, Compostelle, Fatima, Kudüs, Lourdes gibi mukaddes yerlerin ilk sıralarında bulunan mühim hac merkezleridir (Erbaş, 2002: 100). Hristiyanlık tarihinde pek çok ziyaret mekânlarının Anadolu' da olmasıyla bu yerler Hristiyanlığ 1 ve bu tarihte ömrünü, yaşamını geçirmiş mühim kişilerle de alakalıdır. Şu anki yaşamımızda Hristiyan cemiyetleri tarafından ziyaret edilenin önünde dikkat çeken, Pavlus'un misyonerlik seyahatleri sırasında emare bıraktığı mekânlardır. Antalya bu mühim merkezlerden bir tanesidir. Hristiyanlığın burada yaygınlık göstermesi ve bu nedenle de Antakya Kilisesi beş büyük kilise içinde mühim bir destinasyon merkezi olarak yer bulması Petrus, Barbara ve Pavlus gibi mukaddes gördükleri şahsiyetlerin burada ömrünü geçirmesidir. Bunun yanında diğer bir mukaddes yer sayılan Efes olup, yine Pavlus'un burada yaşamış ve Hristiyanlığ 1 yaymaya çalışmış olmasıdır. Yine Hristiyanlık için önem arz eden kişilerden Havari Yuhanna ise burada hayatını sürdürmüş ve vefat ettikten sonra da buradaki yerde toprağa verilmiştir (Özbay vd., 2012: 135).

Dünya üzerinde inanç turizminin yoğunluk gösterdiği yerler şu şekilde sıralanabilir: TürkiyeEfes, Çin-Kailas Dağı, Bangladeş-Tangi, Bosna-Hersek-Medugorje, İtalya-Vatikan-Asisi, Portekiz-Fatima, Fransa-Laurdes, Japonya-Şi Koku, Suudi Arabistan-Mekke-Medine (http://arsiv.ntvmsnbc.com/news/442444.asp, 17.04.2019).

\section{Türkiye'deki İnanç Destinasyonları}

Dini hadise olarak tanınan Tufan hadisesinin, Hz. Nuh Peygamberin gemisinin izlerinin Ağrı Dağı'nda olduğu düşünülmekte ve inceleme, arama çalışması yapılmaktadır. Şanlıurfa Adem Aleyhisselam'ın ömrünü geçirdiği mekan ve İbrahim Aleyhisselam'ın ateşe atıldıği mekan olarak akılda kalmakta ve yine Hz. Adem Aleyhisselam'ın evladı olan Şit Aleyhisselam'ın mezarı da Mersin-Tarsus'ta bulunmaktadır. Önemli kişilerden olan Meryem Ana'nın oğlu Hz. İsa'nın 12 havarisinden birisi olan Aziz Yahya ile birlikte Efes civarlarında ömrünü geçirmiş 
olup; dolaylarında bulunan kabirlerden bir tanesinin ona ait olabileceği ihtimali üzerinde durulmaktadır. Hristiyanlıkta en mühim ikinci adam olarak kabul gören Aziz Pavlus MersinTarsus'ta dünyaya gelmiş ve Anadolu'da Hristiyanlık dinini yaygınlaştırma etkinlikleri yapmıştır. Hristiyan dünyasının ilk kilisesi Saint Pierre Kilisesi (Ki dünyanın en eski ilk Katolik Kilisesi) Hatay-Antakya'dadır. Dört kutsal kitaptan birisi olan İncil'de ismi geçen yedi kilise de Anadolu topraklarında kalmaktadır. Bu kiliselerin adları: Laodicia, Symrna, Thyatira, Sardes, Philadelphia, Ephesus ve Pergamon'dur. Nevşehir'de Hacı Bektaş-1 Veli, İstanbul'da Ayasofya, Konya'da Mevlana, Trabzon ilinde Sümela Manastırı, Antalya-Demre'de Yahudiler için tarihi ehemmiyet arz eden birçok tapınak ve sinagog bulunmaktadır, ayrıca Hristiyanlar açısından önemli olan Aziz Nikola Kilisesi de bulunmaktadır (www.kulturizm.com/region_details.php?B1d=78, 15.06.2009).

\section{Kastamonu İnanç Turizmi}

Kastamonu'da Osmanlı ve Selçuklular dönemine ait olan pek çok külliye, cami gibi türlü inanç merkezleri vardır (Güzey, 2001: 188).

Tablo 1. Kastamonu'daki Türbeler Tablosu

\begin{tabular}{|l|l|}
\hline $\begin{array}{l}\text { Çobanoğlu ve Selçuklu } \\
\text { Dönemine Ait Olan } \\
\text { Türbeler }\end{array}$ & $\begin{array}{l}\text { Vehbi Gazi Türbesi, Karanlık Evliya Türbesi, Muzaffereddin Gazi Türbesi, } \\
\text { Maden Dede Türbesi, Atabeygazi Türbesi, Deveci Sultan Türbesi, } \\
\text { Hepkebirler Türbesi (Batı) ve Müfessir-i Alaaddin Efendi Türbesi'dir. }\end{array}$ \\
\hline $\begin{array}{l}\text { Candaroğulları Beyliği } \\
\text { Dönemine Ait Olan } \\
\text { Türbeler }\end{array}$ & $\begin{array}{l}\text { Harmankaşı Türbesi, Adil Bey Türbesi, İsmail Bey Türbesi, Musa Fakih } \\
\text { Türbesi, Ahi Şorve Türbesi, Kargaş Sultan Türbesi ve Hatun Sultan } \\
\text { Türbesi'dir. }\end{array}$ \\
\hline & Geyikli Sultan Türbesi, Şeyh Mehmed Efendi Türbesi, Şeyh Mustafa \\
& Efendi (Pişküri Zade) Türbesi, İsa Dede Türbesi, Şeyh Mustafa Efendi \\
& (Resul Zade) Türbesi, Topçuoğlu Türbesi, Seyfi Dede Türbesi, Sultan \\
& Türbesi, Molla Said Türbesi, Sacayaklı Sultan (Hasan Efendi) Türbesi, \\
& Kara Mustafa Paşa Türbesi, Benli Sultan Türbesi, Dede Sultan Türbesi, \\
Osmanlı Dönemine Ait & Nasrullah Kadı Türbesi, Hacı Hamza Türbesi, Abdürrezzak Türbesi, \\
Olan Türbeler & Hayran Efendi Türbesi, Halife Sultan Türbesi, Seyyid Sünneti Efendi \\
& Türbesi, Ahmet Dede Türbesi, Nevruz Sultan Türbesi, Karabaş-i Veli \\
& Türbesi, Sükuti Sultan Türbesi, Ferraş Sultan Türbesi, Açıbbaş Sultan \\
& Türbesi, Hacı Dede Türbesi, Hepkebirler Türbesi (Doğu, Abdülcebbar \\
& Türbesi, Bayraklı Sultan Türbesi, Ali Asgar Efendi Türbesi, Dai Sultan \\
& Türbesi ve Cevkani Türbesi'dir. \\
\hline
\end{tabular}

Kaynak: http://www.kastamonukultur.gov.tr/TR63873/inanc-turizmi.html, 17.10.19.

Hanlar, imaretler, hamamlar, külliyeler, camiler ve medreseler gibi tarihi eserler Kastamonu şehrinin turistik alanda kıymetini yükseltirken, aslen Kastamonu şehrinin turizm imkânlarının ne denli zengin olduğunu da gözler önüne sermektedir (İbret, Aydınözü ve Uğurlu 2015: 246).

\section{Kastamonu İli Tarihi ve Kültürel Değerleri}

Çok eski bir yerleşim yeri olan Kastamonu milattan önce 18. Yüzyılda Gas'ların vatanı olmuş, zaman içinde ise Kimmerler, Persler, Pontuslular, Romalılar, Bizanslılar, Frigler, Lidyalılar ve Hititlerin yönetimi altına alınmıştır. Romalıların burada kurduğu Paflagonia adlı eyalet merkezi olan Pompeipolis Höyüğü şimdiki zamanda Taşköprü ilçesinde bulunmaktadır. Bizans hanedanı Komenoslar, aracılığıyla oluşturulan ve ilin tarihsel temelini meydana getiren Kastamonu Kalesi, cezbedici görünüşüyle misafirlerin dikkatini üzerine çekmektedir (Şenol, 2008: 246).

Kastamonu'da birçok sayıda Tümülüs, medrese, cami, kaya mezarı, höyük, kale, köprü ve türbe bulunmaktadır. $\mathrm{Bu}$ açısıyla şehir merkezi ve ilçeler mühim turizm arzını meydana getirmektedir (Baldiran ve Ulubay, 2008: 432). 


\section{Müzeler}

\section{Arkeoloji Müzesi}

Arkeoloji Müzesi 2015 verileriyle 31.282'si sikke olup, toplamda 32.904 adet yapit bulunmaktadır. Arkeoloji Müzesi toplam 3 temel bölümden meydana gelmektedir. İlk bölümde taş yapıtlar seksiyonu ismi altında lahitler, heykeller ve mezar stellerin sergilendiği kısımdır. Bu kısmın en çok ilgi uyandıran yapıtları Tümülüs mezar kazasında bulunan lahit içinde eşyaları ile beraber sergilenen kabir sahibi Satry heykelidir. İkinci bölümde Şapka Devrimi ve Mustafa Kemal Atatürk kısmıdır. Çoğu kişinin bildiği gibi Atatürk Kastamonu ziyaretlerinden Şapka Devrimiyle ilgili ikinci söylevini şimdi müze yapısı olan devir CHP Halk Fırkasında vermiştir. $\mathrm{Bu}$ bölümde Mustafa Kemal ile ilgili eşyalarla reforma ait belgeler sergilenmektedir. Son bölümde ise kronolojik sırayla Kastamonu ve etrafinda bulunmuş, cam, metal, pişmiş toprak, taş eserleri tarih öncesinde Bizans devrine kadar sergilenmektedir. (https://kastamonu.ktb.gov.tr/TR-93949/arkeoloji-muzesi.html, 30.11.2019).

\section{Etnografya Müzesi}

Bodrumu ile beraber tam dört katkı olan konağın üç katı aktif bir şekilde kullanımı yapılmaktadır. 1. katında Kastamonu'nun yakın zamanıyla alakalı resimlere ilişkin müze kitaplığı ve sergi yer almaktadır. 2. Katındaysa binlerce senelik sanatlarının ve halk kültürünün sergilendiği bir yerdir. Müzenin en üst katındaysa Kastamonu konağının yerleşmesinin, odaların fonksiyonlarının cansız mankenler ile canlandırıldığ 1 bir kısımdır. (https://kastamonu.ktb.gov.tr/TR-93950/etnografya-muzesi.html, 30.11.2019).

\section{Şeyh Şaban-ı Veli Vakıf Müzesi}

Müzede bulunan yapıtların çoğunluk gösteren kısmı Kastamonu ilinden, bir kesimi de Vakıflar bölge Müdürlüğü'nün mesuliyetinin olduğu şehirlerden toplanan yapitlardan meydana gelmektedir. Müzenin içindeki temel yapıt kümeleri Hz. Pir Şeyh Şaban-1 Veli'nin şahsi eşyaları, hatlar, halılar, kandiller ve el yazmalarıdır. Her biri birbirinden kıymetli bu yapıtlar içerisinde; 1600'lü senelerden kaldığı bilinen ve çok mühim alışkanlıkları gösteren sadaka taş1, 1182 senesinden kaldığ 1 bilinen kutsal kitabımız Kur'an-1 Kerim ve stil kritik bakımından Kastamonu iline mahsus olan kandiller ve Şeyh Şaban-1 Veli'nin şahsi yapıtları bayağı rağbet görmektedir. Günümüzde de Şeyh Şaban-1 Veli Vakıf Müzesi, ziyaret edenlerine karşı hiçbir ücret talep etmeden hizmet sunmaktadır (https://kastamonu.ktb.gov.tr/TR-93951/seyh-saban-iveli-vakif-muzesi.html, 30.11.2019)

\section{Külliyeler}

\section{Nasrullah Kadı Külliyesi}

Şehir merkezinde bulunan köprüsü, camisi, şadırvanı, meydanı ve daha sonradan ilave edilen medresesiyle külliye görünüşündedir. 2. Beyazıd devrinde 1506 senesinde Nasrullah Kadı aracılığıyla şadırvan ve köprü içerisindeki su havuzlarıyla beraber meydana getirilen cami Kastamonu ilinin en büyük camisi niteliğindedir. 1746 senesinde büyütülmesine kadar altı kubbeli bünyeye sahip olan cami, bu yapılan çalışmayla dokuz kubbeli duruma gelmiştir. Cami içindeki süslemeler ve hatlar ise gene Kastamonulu Ahmet Şevki Efendi aracıllğıyla yazıldığı bilinmektedir. Milli mücadele senelerinde, Anadolu'yu gezerek Kurtuluş Harp'ine yardım toplayan Mehmet Akif Ersoy, Nasrullah Camisi'nde de halka karşı vaaz vermiş ve halka Milli Mücadele amacıyla cesaret vermiştir. Nasrullah Camisi şadırvanı içerisindeki su havuzları 1506 senesinde camiyle beraber inşa edilirken, şadırvan bölümüyse iki kubbeli bir şekilde 1752 senesinde Bedii isimli yardımsever aracılığıyla oluşturulmuştur. Halk içerisinde yaşayan bir efsaneye bakılırsa, burada bulunan şadırvandan bir kere bile su içtiğinde ya Kastamonu şehrine 
yerleşmekte ya da sürdürdüğ̈ hayatında tam yedi kere Kastamonu'ya seyahat etmektedir (https://kastamonu.ktb.gov.tr/TR-93960/nasrullah-kadi-kulliyesi.html, 01.12.2019).

\section{İsmailbey Külliyesi}

Şehir merkezinde İsmail Bey Mahallesi'nde bulunan külliye, üstünde milattan önce 7. yüzy1la ilişkin iki tane kaya kabrine sahip Şahinşah Kayası üstünde bulunmaktadır. Candaroğullarının en son hükümdarı olan İsmail Bey aracılığıyla meydana getirilen külliye içinde kütüphane, medrese, han, hamam, türbe ve camiden beylikler dönemi zanaatının en iyi misallerini sergileyen binalar cemiyeti yer almaktadır (https://kastamonu.ktb.gov.tr/TR-93961/ismailbeykulliyesi.html, 01.12.2019).

\section{Yakupağa Külliyesi}

1547 senesinde Yakup Ağa aracılığı ile oluşturulmuştur. Sıbyan Okulu, imaret, misafirhane ve medreseden oluşmaktadır. Cami: Yapılış yöntemi itibarı ile mimari bir değere sahip olduğu gibi imaret, sıbyan mektebi ve medreseye sahip bir külliyenin içerisinde olduğu için de başkaca kıymetlidir. Aşevi (İmarethane): Yakup Ağa aşevinde, bir günün bütün saatinde sıcak çorba olduğu, bu aşevi kapısının her zaman açık bulunduğu, fakir zengin ayrımı yapmadan, gelen her kişiye ikramların olduğu anlatılmaktadır. Ağa aşevi olarak hatırlanmasının sebebi bu aşevinin halk üstünde bıraktığ 1 güzel ve olumlu tesirdir. Sıbyan Okulu: 5-10 yaş arasinda olan kız ve erkek çocuklarına yazma, okuma, öğretilen ve din eğitimi verilen sıbyan okulu bugünümüzde el zanaatları satış alanı olarak kullanımı söz konusu olmaktadır. Medrese: Külliyenin başka bir bölümünü meydana getiren medrese güneyinde tonoz örtülü odalar ve giriş yerinde üstü kubbeli odalar bulunmaktadır. (https://kastamonu.ktb.gov.tr/TR-93962/yakupaga-kulliyesi.html, 01.12.2019).

\section{Şeyh Şaban-ı Veli Külliyesi}

Hz. Pir Şeyh Şaban-1 Veli, 1481 senesinde Kastamonu şehri Taşköprü ilçesinde doğmuştur (Avc1, 2019: 34). Ufak yaşlarda baba ve annesini yitiren Hz. Pir Şeyh Şaban-1 Veli, hayır sahibi bir kadın tarafından eğitimi üstlenerek hadis-tefsir eğitimini Kastamonu ve Taşköprü'de almış bulunmaktadır (Çiftçi, 2002: 95). Bu öğrenimlerinin arkasından bir kadın tarafından daha üst seviye tasavvuf eğitimi amaciyla İstanbul'a gönderilen Hz. Pir Şeyh Şaban-1 Veli, II. Beyazıt aracılığıyla Fatih Medreselerinde dini eğitimlerini bitirerek, tasavvuf sahasına doğru yönelme göstermiştir (Tatc1, 2012: 31).

Kastamonu ili, şu anki zamanımızda gerek kültürel potansiyeli ve gerek tarihsel bütünlügüyle nahiyenin turizm açısından mühim illeri içerisinde yerini almaktadır. İl, Türklerin hâkimiyetine geçtikten sonra da kültür, güvenlik ve ticaret yönünden mühim bir yerde olmasından ötürü, topraklarında Türk ve İslam tarihi bakımından mühim mimari yapıtları ve kişileri barındırmaktadır (Yakupoğlu, 2009: 508).

Kastamonu ili inanç dünyasında ön planda olan en gözde dini kişi ve yer, Hz. Pir Şeyh Şaban-1 Veli ve Şeyh Şaban-1 Veli külliyesidir (İçerisinde; Cami, türbe, Asa suyu, mezarlık ve müze bulunmaktadır (Karabaltaoğlu, 2019: 18).

Hz. Pir Şeyh Şaban-1 Veli inanç ve kişilik yönünden muhteşem bir şahsiyettir. İslam dinine çok bağlı kalmıştır. Yaşantısı ile örnek bir bireydir. Bu şahsiyet inanç turizminde Kastamonu açısından önemli potansiyele ve etkiye sahiptir. Şeyh Şaban-1 Veli Külliyesi ise; görünüşü itibarıyla gelen ziyaretçileri etkisi altına almaktadır. Külliye manevi ortamı ile misafirlere mutluluk ve huzur vermektedir. İnsanlar kendilerini arınmış hissetmektedirler. 


\section{Camiler}

\section{Mahmutbey Camii}

Mahmut Camisi'nin çatısı bindirme tekniği denilen bir yöntemle yapılmış, rastgele bir aksam ve hiç metal çivi kullanılmaması ile Türkiye'de görülen çok nadir örnekten bir tanesidir. Cami içindeki bütün ahşap olan yüzeyler kökboyası ile kalem işi süsleme işleme yapılmış ve bu yapılan süslemeler hala daha orijinal durumuyla kalmaktadır (https://kastamonu.ktb.gov.tr/TR93964/mahmutbey-camii.html, 01.12.2019).

\section{Atabeygazi Camii}

Atabeygazi Camisi Muzaffereddin Yavlak Aslan Bey aracılığı ile 13. yüzyılın ikinci yarısında ve 1273 senesinde oluşturulmuştur. Kentin en eski olan camisi olarak bilinmektedir. Duvarlar1 moloz taşından ve kesme taştan meydana getirilmiştir. 40 adet direk üzerine geçirilen ahşap bir tavan bulunmaktadır. Bu sebep ile kamu içinde de 'Kırk Direkli Camii' olarak da adından söz ettirmektedir (https://kastamonu.ktb.gov.tr/TR-93965/atabeygazi-camii.html, 01.12.2019).

\section{Yılanlı Camii}

Dikdörtgen şeklinde planlanmış bir yapısı bulunmakta ve moloz taşlardan yapılmaktadır. Çatısı ahşap üstü kiremit örtülü vaziyettedir. Kaidesi kesme taştan yapılan minarenin gövde kısmı tuğladan oluşturulmuştur. 1937 senesinde yanmış olan yapı tekrar yapılmıştır. Yapılan onarım çalışmalarında ahşap çatısı tamir edilmiş, dış cephe derzleri ve iç sıvalarının yenileme işlemleri yapılmıştır. $\mathrm{Bu}$ cami ibadet etmeye açık bir durumdadır (https://kastamonu.ktb.gov.tr/TR95231/yilanli-camii.html, 01.12.2019).

\section{Metot}

$\mathrm{Bu}$ araştırmada sosyal bilimlerde araştırma yöntemlerinden olan nitel araştırma metodu kullanılmıştır. Bu araştırma kapsamında gözlem yapma ve belge çözümlemesi gibi nitel bilgi elde etme vasıtalarından faydalanılarak olay ve algının doğal yerinde bütün olarak ve gerçeğe uygun şekilde meydana getirilmesinde dönük bir prosesin takip edildiği nitel araştırma metodu kullanılması planı yapılmaktadır. Nitel araştırmada asıl gaye genelleme yapılması değil de tüm bir görüntü sağlamaktır. Araştıılan konu en ince ayrıntısına kadar derin bir şekilde ele alınır. Nitel araştırma teori üretmeyi esas alan yaklaşımla toplumsal olguyu ait oldukları çevre içinde vukufu öne çıkaran bir yaklaşım türüdür. (Bardakoğlu, 2011: 90).

$\mathrm{Bu}$ araştırmada nitel veri toplama aracı doküman analizi tekniğidir. Belge çözümlemesi araştırılması maksut olay ve olgu üzerine malumat barındıran yazılı gereçlerin analiz edilmesini kapsamı altına almaktadır. Belge çözümlemesi nitel araştırmada sadece kendisi bilgi edinme metodu olabileceği gibi başka bilgi edinme metotlarıyla bir arada kullanılması mümkündür (Şimşek, 2009: 42).

Yapılan bütün görüşmeler neticesinde sağlanan donelere muhteva çözümlemesi uygulanmıştır. Muhteva çözümlemesi; pek türlü söyleme uygulanan bazı metodolojik vasita ve becerilerin tamamı denebilmektedir (Bilgin, 2000: 1).

Araştırmanın amacı unutulmaya yüz tutmuş değerlerimizi yaşatmak, turizm potansiyelini değerlendirmek, avantajlarını ve dezavantajlarını ölçmek, şehirdeki turizmin önündeki sorunları belirleyip çözüm önerileri sunmak ve son olarak da turizm bilinci geliştirmektir.

Araştırma büyük önemi arz etmektedir. Kastamonu ili dini açıdan Türkiye'de çok önemli bir yere sahiptir. Yaklaşık 17 bin evliyanın yaşadığı düşünülmekte bu da dini ve ruhsal açıdan inanç turizminin önemine vurgu yapmaktadır. Sahip olduğu doğa ve tabiat güzelliklerinin yanı sıra birçok turizm türüne ev sahipliği yapmaktadır. Özellikle 2018 yılında Türk Dünyası Kültür Başkenti oluşu markalaşma, reklam, tanıtım ve popülaritesi için pozitif izlenim yaratmaktadır. 
Kastamonu özellikle doğal yaşantısı, kültürel değerleri, sosyal yapısı, çevresel mimarisi ve tarihi ile yaşatılması gereken en nadide şehirlerden bir tanesidir. Değerlerimizi yaşatmak, korumak ve yeni nesillere aktarmak birey, aile ve toplum için önem arz etmektedir.

$\mathrm{Bu}$ araştırma kapsamında, öğrencilere ve akademisyenlere ulaşılmıştır. 30 adet kişiye ulaşılmıştır. Araştırmanın özgünlüğü için intihal oranının düşük seviyelerde olmasına dikkat edilmiştir. $\mathrm{Bu}$ çalışmadan turizm işletmeleri, turistler ve yerli halk yararlanabilir. Çalışma yürütülürken etik kurallara uyma ve tepki çekmemek esas alınmıştır. Araştırmanın özgün olabilmesi için yeni fikirler ve uygulamalar öne sürülmeye gayret gösterilecektir. Araştırma kısmında; akademisyenlerden ve öğrencilerden yararlanılmıştır.

Araştırmanın evreni; Kastamonu İlidir. Çalışma evreni ise; Kastamonu İli Merkez İlçesi'dir. Kastamonu Üniversitesi Turizm Fakültesindeki öğrenci ve akademisyenlerinden araştırma kısmında yararlanılmıştır. Kartopu örneklemine başvurulmuştur. $\mathrm{Bu}$ örneklemde 30 kişiye ulaşılmış, belli bir kanıya varılmıştır.

\section{Bulgular}

Araştırmaya katılanların 17'si (\%56.6) erkek, 13'ü (\%43,3) kadındır. 18-20 yaş arasında olanlar 4 kişi (\%13.3), 21-30 yaş arasında olanlar 22 kişi (73.3), 30-40 yaş arasında olanlar 2 kişi (\%6.6), 40-50 yaş arasında olanlar 1 kişi (\%3.3), 60-70 yaş arasında olanlar ise 1 kişidir (\%3.3). Evli olanlar 5 kişi (\%16.6), bekâr olanlar ise; 25 kişidir (\%83.3). 1 seneden az çalışanlar; 16 kişi (\%53.3), 1-3 sene arasında çalışanlar 5 kişi (\% 16.6), 4-7 sene arasında çalışanlar 5 kişi (\%16.6), 8-11 sene arasında çalışanlar 1 kişi (\%3.3), 12-15 sene arasında çalışanlar 1 kişi (\%3.3), 15 sene ve üzerinde çalışanlar ise 1 kişidir (\%3.3). Lisans okuyanlar 15 kişi (\%50), lisansüstü okuyanlar ise 15 kişidir (\%50). 1001-2000 TL arası gelire sahip olanlar 19 kişi (\%63.3), 2001-3000 TL aras1 gelire sahip olanlar 2 kişi (\%6.6), 3001-4000 TL aras1 gelire sahip olanlar 2 kişi (\%6.6), 5000-10000 TL arası gelire sahip olanlar ise 7 kişidir (\%23.3). Akademisyen olanlar 7 kişi (23.3), öğrenci olanlar ise 23 kişidir (\%76.6). Katılımcıların hepsi turizm sektöründe çalışmışlardır.

Tablo 2. Bulgular Tablosu

\begin{tabular}{|c|c|c|c|}
\hline $\begin{array}{l}\text { Sorun } \\
\text { Sinif } \\
\text { No }\end{array}$ & Açıklama & $\begin{array}{l}\text { Toplam } \\
\text { Görüş }\end{array}$ & $\begin{array}{l}\text { Kat1lımc1 } \\
\text { No }\end{array}$ \\
\hline Soru 1 & Kastamonu'da inanç turizmi denince akla neler gelmektedir? & & \\
\hline A) & $\begin{array}{l}\text { Kastamonu ili türbe, han, hamam, kervansaray, cami, dini festival } \\
\text { ve törenlerin, pirlerin ve azizlerin bulunduğu topraklar üzerinde } \\
\text { kalmaktadır. Kastamonu'da inanç turizmi denilince akla ilk olarak } \\
\text { Hz. Pir Şeyh Şaban-1 Veli gelmektedir. Şeyh Şaban-1 Veli } \\
\text { Külliyesi, Asa Suyu (Şeyh Şaban-1 Veli Külliyesi içerisinde } \\
\text { bulunmaktadır), Nasrullah Camisi, Sinanbey Camisi, Ayağı Yanık } \\
\text { Baba Türbesi, Yılanlı Camii, Yakup Ağa Külliyesi, Mahmut Bey } \\
\text { Camisi, İsmail Bey Külliyesi, Pompeipolis Antik Kenti, Ayağı } \\
\text { Yanık Türbesi, Mehmet Feyzi Efendi Türbesi, Atabey Gazi } \\
\text { Türbesi, Maden Dede Türbesi, Aşıklı Sultan Türbesi, Nasrullah } \\
\text { Külliyesi, Kastamonu Kalesi diğer bilinenler arasındadır. }\end{array}$ & 30 & $\begin{array}{l}1,2,3,4,5,6, \\
7,8,9,10,11 \\
, 12,13,28,2 \\
9,3015,16, \\
17,18,19,2 \\
0,21,22,23, \\
24,25,26,2 \\
7,14,\end{array}$ \\
\hline B) & $\begin{array}{l}\text { Kastamonu şehrinin } 2018 \text { yılında Türk Dünyası Kültür Başkenti } \\
\text { seçilmesi inanç turizminde çok büyük bir potansiyel teşkil } \\
\text { etmektedir. }\end{array}$ & 1 & 20 \\
\hline C) & Evliyalar şehri olarak bilinmektedir. & 1 & 25 \\
\hline Soru 2 & Kastamonu'da gerçekleştirilen turizm çeşitleri nelerdir? & & \\
\hline & Kastamonu'da kış turizmi, inanç turizmi, kültür turizmi, & 29 & $1,2,3,4,5,7$, \\
\hline
\end{tabular}

July-2020 Vol:5 No:1 International Journal of Turkic World Tourism Studies 


\begin{tabular}{|c|c|c|c|}
\hline A) & $\begin{array}{l}\text { gastronomi turizmi ve ormancllık ve tabiat turizmi en çok bilinen } \\
\text { turizm çeşitleri arasindadır. Kastamonu şehrinde az bilinen turizm } \\
\text { çeşitleri arasında doğa turizmi, trekking, kongre turizmi, kitle } \\
\text { turizmi, av turizmi, eko turizm, deniz turizmi, sağlık turizmi, } \\
\text { çiftlik turizmi, macera turizmi gelmektedir. }\end{array}$ & & $\begin{array}{l}8,9,10,11,1 \\
2,13,14,15 \\
16,17,18,1 \\
9,20,21,22, \\
23,24,25,2 \\
6,27,28,29 \\
30\end{array}$ \\
\hline B) & $\begin{array}{l}\text { Sürdürülebilir turizm gerçekleştirilmektedir. Bu bir turizm türü } \\
\text { değildir. Sürdürülebilmeyi amaç edinmektedir. Turizm çeşitlerinin } \\
\text { devamlıllk göstermesi için önem arz etmektedir. }\end{array}$ & 1 & 6 \\
\hline Soru 3 & $\begin{array}{l}\text { Kastamonu'da turizmin gelisstirilmesine yönelik ne gibi } \\
\text { faaliyetler gerçekleştirilebilir? }\end{array}$ & & \\
\hline A) & $\begin{array}{l}\text { Şehir planlamasına turizm dâhil edilerek gerekli çalışmalar } \\
\text { yapılmalıdır. }\end{array}$ & 2 & 1,28 \\
\hline B) & $\begin{array}{l}\text { Yerel halk ve işletmeciler turizm konusunda bilinçlendirilmelidir. } \\
\text { Farkındalık oluşturmak dikkat çekmeyi sağlamaktadır. }\end{array}$ & 6 & $\begin{array}{l}2,4,11,18,2 \\
0,22\end{array}$ \\
\hline C) & $\begin{array}{l}\text { Reklam ve tanıtım faaliyetleri gerçekleştirilmelidir. Doğru } \\
\text { pazarlama stratejileri uygulanabilir. Alternatif turizm } \\
\text { uygulamaları piyasaya sunulmalıdır. }\end{array}$ & 14 & $\begin{array}{l}3,5,8,9,10 \\
13,14,15,1 \\
6,18,25,26 \\
29,30\end{array}$ \\
\hline D) & Altyapıya önem verilmelidir. & 4 & $4,5,11,23$ \\
\hline E) & Turistik geziler düzenlenmelidir. & 2 & $6,8,30$ \\
\hline F) & Doğa ve tabiata önem verilmelidir. & 3 & $7,16,17$ \\
\hline G) & Festival ve etkinlikler gibi çeșitli aktiviteler düzenlenmelidir. & 2 & 9,10 \\
\hline H) & $\begin{array}{l}\text { Turistlere yardımcı olma açısından rehber bulundurulması } \\
\text { önemlidir. }\end{array}$ & 1 & 12 \\
\hline I) & Yabancı dil öğrenilmelidir. & 1 & 17 \\
\hline I) & $\begin{array}{l}\text { Sağlık turizmi alanında çalışmalar yapmak ve Kastamonu'da bir } \\
\text { rehabilitasyon merkezi kurmak şehir açısından önem taşımaktadır. }\end{array}$ & 1 & 19 \\
\hline J) & Yaz turizmine yönelinebilir. & 1 & 21 \\
\hline K) & $\begin{array}{l}\text { Doğa turizminin geliştirilmesi için uygun çalışmalar başlatılmalı } \\
\text { ve devam ettirilmelidir. }\end{array}$ & 1 & 24 \\
\hline L) & $\begin{array}{l}\text { Bölgesel kalkınma ajansları tarafindan turizme verilen destekler } \\
\text { artırılabilir. }\end{array}$ & 1 & 27 \\
\hline Soru 4 & $\begin{array}{l}\text { Kastamonu halkının gelen turistlere bakış açısını nasıl } \\
\text { değerlendirirsiniz? }\end{array}$ & & \\
\hline A) & $\begin{array}{l}\text { Olumsuz bir bakış açısı vardır. Misafirperver bir tutum } \\
\text { sergilenmemektedir. }\end{array}$ & 4 & $1,2,11,23$ \\
\hline B) & $\begin{array}{l}\text { Bölge halkının iletişim kurarken utangaç bir tutum sergilemesi ve } \\
\text { çekimser olması turistleri olumsuz etkilemektedir. }\end{array}$ & 2 & 3,4 \\
\hline C) & $\begin{array}{l}\text { Bakış açıları olumludur. Turistlere karşı yakın davranılmaktadır. } \\
\text { Bölge halkı turistlere karşı misafirperver ve yardımseverdir. } \\
\text { Anlayışlı davranışlar ön plandadır. Hoşgörülü ve naziktirler. Sıcak } \\
\text { ve samimi davranışlar sosyal dayanışmayı artırmaktadır. Ülkeye } \\
\text { turizm faaliyetlerinde ekonomik gelir kazandırmaktadır. Tanıtım } \\
\text { etkinlikleri etkin kullanılmaya çalışıllmaktadır. }\end{array}$ & 19 & $\begin{array}{l}5,6,8,9,12 \\
13,15,16,1 \\
7,18,19,20 \\
21,24,25,2 \\
6,27,29,30\end{array}$ \\
\hline D) & $\begin{array}{l}\text { Halkın bilinçlendirilmesiyle turizm ve turistlere karşı olumlu } \\
\text { görüşler sağlanacaktır. }\end{array}$ & 2 & 7,22 \\
\hline E) & Turistlere karş1 önyargılı bir tutum sergilenmektedir. & 2 & 10,14 \\
\hline F) & - & 1 & 28 \\
\hline Soru 5 & $\begin{array}{l}\text { Kastamonu'da gerçeklesstirilen festivaller ve etkinlikler } \\
\text { nelerdir ve bölge halkına katkısı nasıldır? }\end{array}$ & & \\
\hline & Gastronomi Festivali, Taşköprü Kültür Ve Sarımsak Festivali, & 24 & \\
\hline
\end{tabular}

July-2020 Vol:5 No:1 International Journal of Turkic World Tourism Studies 


\begin{tabular}{|c|c|c|c|}
\hline A) & $\begin{array}{l}\text { Tosya Pirinç Festivali, Cide Sarı Yazma Festivali, Nevruz } \\
\text { Bayramı, Kültür Ve Turizm Bakanlığı’nın yaptığı etkinlikler, } \\
\text { Tosya Yağlı Güreş Festivali, Halk Oyunları Festivali (özellikle } \\
\text { köçek dansı öne çımaktadır), İhsangazi Sepetçioğlu ve Siyez } \\
\text { Bulguru Festivali, Ilgaz Kayak Festivali gibi festival ve etkinlikler } \\
\text { gerçekleştirildiği bilinmektedir. } \\
\text { Bu festivaller ve etkinliklerin önce Türkiye'de çapında daha sonra } \\
\text { dünya çapından tanıtılması ve önem kazandırılması } \\
\text { gerekmektedir. Kastamonu ilinin birçok ilçesinde de külttür ve } \\
\text { sanat etkinlikleri düzenlenmektedir. } \\
\text { Kastamonu'da yemek, doğa, kültür ve din alanlarında birçok } \\
\text { festivaller gerçekleştirilmektedir. Bu festivallerde yöre halkının } \\
\text { sahip olduğu kültürel mirası yaşayan başta ülkemiz insanları } \\
\text { olmak üzere tüm dünyaya yansıtma firsatı elde etmektedir. } \\
\text { Festivaller ve etkinliklerin bölge halkına gelir sağlayıcı bir etkisi } \\
\text { bulunmaktadır. Yerli halka diğer etkisi manevi ortamı olumlu } \\
\text { yönde etkilemektedir. Sosyal kaynaşmayı artırmaktadır. Halka } \\
\text { turizm konusunda bilinç kazandırır. }\end{array}$ & & $\begin{array}{l}1,2,4,7,8,9, \\
10,11,13,1 \\
4,15,17,18, \\
19,20,21,2 \\
2223,24, \\
25,26,27,2 \\
8,30\end{array}$ \\
\hline B) & $\begin{array}{l}\text { Anma haftaları, İstiklal Yolu anma haftası, Şeyh Şaban-1 Veli } \\
\text { anma haftası geleneksel bir şekilde tertip edilmektedir. }\end{array}$ & 9 & $\begin{array}{l}2,6,11,13,1 \\
6,17,20,21, \\
24\end{array}$ \\
\hline C) & $\begin{array}{l}\text { Rehber eşliğinde turistlere yönelik gezi düzenlenmektedir. Bu } \\
\text { durum bölge tanıtımı ve ekonomik kalkınma için önem teşkil } \\
\text { etmektedir. }\end{array}$ & 1 & 3 \\
\hline D) & $\begin{array}{l}\text { Festival yetersizliği mevcut, tanıtım ve önemi için daha çok } \\
\text { aktivite alanı olması ve etkinliklerin artması gerekliliği } \\
\text { vurgulanmaktadır. }\end{array}$ & 1 & 5 \\
\hline E) & - & 2 & 12,29 \\
\hline Soru 6 & Kastamonu denince akla hangi yemekler gelmektedir? & & \\
\hline A) & $\begin{array}{l}\text { Kastamonu denince akla; Alıç Meyvesi, Banduma, Bulgur Pilavı, } \\
\text { Cabada Güveç, Cırık Tatlısı, Cızlama, Çekme Helva, Döner, } \\
\text { Dügüün Böreği, Ecevit Çorbası, Ekşili Pilav, Etli Ekmek, Etli Pide, } \\
\text { Gözleme, Kara Çorba, Kaşık Helvası, Kelle Paça Çorbası, } \\
\text { Keşkek, Kel Simit, Köle Hamuru, Kuyu Kebabı, Muska Baklava, } \\
\text { Pastırma, Pastırmalı Ekmek, Saray Şerbeti, Sarımsak, Simit } \\
\text { Tiridi, Siyez Bulguru Pilavı, Tarhana Çorbası, Tas Kebabı, Taş } \\
\text { Helvası, Tirid, Üryani Eriği gelmektedir. } \\
\text { En popüler bulunan yiyecekler ise; Banduma, Cırık Tatlısı, } \\
\text { Çekme Helva, Ecevit Çorbası, Etli Ekmek, Kara Çorba, Bulgur } \\
\text { Pilavı, Keşkek, Kuyu Kebabı, Pastırma, Pastırmalı Ekmek, } \\
\text { Sarımsak, Tirit, Tas Kebabı Ve Taş Helvasıdır. }\end{array}$ & 30 & $\begin{array}{l}1,2,3,4,5,6, \\
7,8,9,10,11 \\
, 12,13,14, \\
5,16,17,18, \\
19,20,21,2 \\
2,23,24,25, \\
26,27,28, \\
29,30\end{array}$ \\
\hline
\end{tabular}

\section{Tartışma ve Sonuç}

Kastamonu doğal, kültürel ve tarihi mekânlar bakımından çok zengin bir topraklar üzerinde bulunmaktadır. Kastamonu'da inanç turizmi denince akla türbe, han, hamam, kervansaray, cami, dini festival ve törenlerin, pirlerin ve azizlerin bulunduğu topraklar zihinlerde yer almaktadır. Kastamonu'da inanç turizmi denilince akla ilk olarak Hz. Pir Şeyh Şaban-1 Veli gelmektedir. Şeyh Şaban-1 Veli Külliyesi, Asa Suyu (Şeyh Şaban-1 Veli Külliyesi içerisinde bulunmaktadır), Nasrullah Camisi, Sinanbey Camisi, Ayağı Yanık Baba Türbesi, Yılanlı Camii, Yakup Ağa Külliyesi, Mahmut Bey Camisi, İsmail Bey Külliyesi, Pompeipolis Antik Kenti, Ayağı Yanık Türbesi, Mehmet Feyzi Efendi Türbesi, Atabey Gazi Türbesi, Maden Dede Türbesi, Aşıklı Sultan Türbesi, Nasrullah Külliyesi, Kastamonu Kalesi diğer bilinenler arasındadir. 
Kastamonu şehrinin 2018 yılında Türk Dünyası Kültür Başkenti seçilmesi inanç turizminde çok büyük bir potansiyel teşkil etmektedir. $\mathrm{Bu}$ anlamda birçok reklam, tanıtım, tutundurma faaliyetleri gerçekleştirilmiştir. Popülerliği artmış ve Türk Dünyası ülkeleri arasında ve dünyada saygınlık kazanmıştır. 17 bin evliyanın burada yaşamış olması evliyalar şehri diye de anılmaktadir.

Kastamonu'da kış turizmi, inanç turizmi, kültür turizmi, gastronomi turizmi, ormancılık ve tabiat turizmi en çok bilinen turizm çeşitleri arasındadır. Kastamonu şehrinde az bilinen turizm çeşitleri arasında doğa turizmi, trekking, kongre turizmi, kitle turizmi, av turizmi, eko turizm, deniz turizmi, sağlık turizmi, çiftlik turizmi, macera turizmi gelmektedir. Altyapı ve üst yapının da gelişmesiyle beraber daha önemli değişimler kaydedilecektir. Reklam ve tanıtım faaliyetleri geliştirilerek, gerekli bütçeler oluşturularak Kastamonu ilinde yapılan turizm çeşitlerinin çoğaltılması hedeflenmektedir. İlde sürdürülebilir turizmde gerçekleştirilmektedir. Turizm çeşitlerinin devamlılık göstermesi için önem arz etmektedir. İl içerisinde Şehir planlamasına turizm dâhil edilerek gerekli çalışmalar yapılmalıdır. Yerel halk ve işletmeciler turizm konusunda bilinçlendirilmelidir. Farkındalık oluşturmak dikkat çekmeyi sağlamaktadır. Doğru ve etkin pazarlama stratejileri uygulanmalıdır. Böylece hedef kitleye erişim sağlanabilir. Onların istek ve ihtiyaçları sorunsuz ve kısa bir zaman içinde yerine getirilebilir. Doğa ve tabiata önem verilmelidir. Turizm sektöründe çevreye zarar vermemek hep ön planda olmuştur. Doğal güzellikleri olan bir şehri her turist ziyaret etmek ister.

Kastamonu halkının gelen turistlere bakış açısı büyük oranla olumlu olarak bulunmuştur. Turistlere karşı cana yakın, samimi ve güler yüzlü davranılmaktadır. Bölge halkı turistlere karşı misafirperver ve yardımseverdir. Anlayışlı davranışlar ön plandadır. Hoşgörülü ve naziktirler. Sıcak ve samimi davranışlar sosyal dayanışmayı artırmaktadır. Ülkeye turizm faaliyetlerinde ekonomik gelir kazandırmaktadır. Az oranda ise; Misafirperver olmayıp kaba olanlar sadece gelir kaynağı olarak görenlerde vardır. Halkın bilinçlendirilmesiyle turizm ve turistlere karşı olumlu görüşler sağlanacaktır.

Kastamonu'da Gastronomi Festivali, Taşköprü Kültür Ve Sarımsak Festivali, Tosya Pirinç Festivali, Cide Sarı Yazma Festivali, Nevruz Bayramı, Kültür Ve Turizm Bakanlığı'nın yaptığı etkinlikler, Tosya Yağlı Güreş Festivali, Halk Oyunları Festivali (özellikle köçek dansı öne çıkmaktadır), İhsangazi Sepetçioğlu ve Siyez Bulguru Festivali, Ilgaz Kayak Festivali gibi festival ve etkinlikler gerçekleştirildiği bilinmektedir. $\mathrm{Bu}$ festivaller ve etkinliklerin önce Türkiye'de çapında daha sonra dünya çapından tanıtılması ve önem kazandırılması gerekmektedir. Kastamonu ilinin birçok ilçesinde de kültür ve sanat etkinlikleri düzenlenmektedir. Kastamonu'da yemek, doğa, kültür ve din alanlarında birçok festivaller gerçekleştirilmektedir. Bu festivallerde yöre halkının sahip olduğu kültürel mirası yaşayan başta ülkemiz insanları olmak üzere tüm dünyaya yansıtma firsatı elde etmektedir. Festivaller ve etkinliklerin bölge halkına gelir sağlayıcı bir etkisi bulunmaktadır. Yerli halka diğer etkisi manevi ortamı olumlu yönde etkilemektedir. Sosyal kaynaşmayı artırmaktadır. Halka turizm konusunda bilinç kazandırır. Kentte çeşitli anma etkinlikleri de yapılmaktadır. Bu da sosyal yardımlaşma ve dayanışmaya katkı sağlamaktadır. İnsanlar buraların manevi havasını soluyarak kendilerini daha mutlu ve daha zinde hissetmektedirler.

Şehrin en çok tanınan yiyecekleri ise; Banduma, Cırık Tatlısı, Çekme Helva, Ecevit Çorbası, Etli Ekmek, Kara Çorba, Bulgur Pilavı, Keşkek, Kuyu Kebabı, Pastırma, Pastırmalı Ekmek, Sarımsak, Tirit, Tas Kebabı ve Taş Helvasıdır.

Kastamonu'nun altyapı ve üst yapısı gerekli destek sağlanarak geliştirilmelidir. Dijital platformlarda kendisini mükemmel bir şekilde tanıtmalıdır. Dijital dünyada akılda kalmak ve hatırlanmak önemlidir. Reklam, tanıtım, fiyatlandırma, özendirme, tutundurma faaliyetleri ve 
çeşitli diğer ürünlerle daha geniş müşteri kitlesine ulaşılmaktadır. Dijital medya kullanımı misafir memnuniyeti ve sadakati üzerinde önemli bir role sahiptir.

Kastamonu İli Türkiye'nin en önemli tarih ve kültür merkezlerinden bir tanesidir. İçerisinde barındırdığı pek çok müze, han, hamam, kervansaray, cami, mescit, kale, kule, mesire alanları, doğal, tarihi ve kültürel açıdan önemli sayılacak mekânlar ile adeta insanları kendine büyülemektedir. Kendine has doğal, tarihi ve kültürel çekiciliklerinin olması, bunların muhafaza edilmesiyle Kastamonu diğer illerle kıyaslandığında bir farkındalık ortaya koymaktadır.

Kastamonu birçok medeniyetlere de ev sahipliği yapmıştır. Zaman içinde üzerinde bulunduğumuz bu muhteşem topraklar bu doğrultuda şekillenmiştir. Kastamonu ilinde birçok turizm türleri de uygulanabilmektedir; Kültür turizmi, kongre turizmi, ormancılık ve tabiat turizmi, inanç turizmi, deniz turizmi (deniz, kum, güneş üçlüsü dikkat çekici etkiye sahip), kış turizmi (Ilgaz ve Küre dağları milli parkları önemli sayılabilen mekânlardır) ve kitle turizmi örnek gösterilebilmektedir. 


\section{Ekler}

Tablo 3. Katılanların Demografik Özellikleri Tablosu

\begin{tabular}{|c|c|c|c|c|c|c|c|}
\hline 离 & 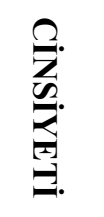 & 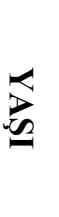 & 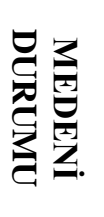 & 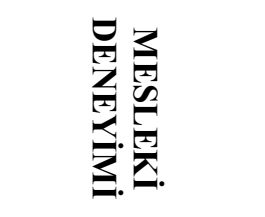 & 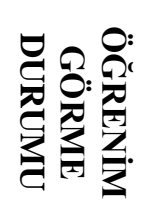 & 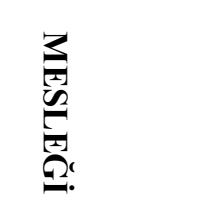 & 通 \\
\hline 1 & Erkek & 18 & Bekâr & 1 seneden az & Lisans & Öğrenci & $1001-2000 \mathrm{TL}$ aras1 \\
\hline 2 & Erkek & 22 & Bekâr & 1 seneden az & Lisans & Öğrenci & 2001-3000 TL aras1 \\
\hline 3 & Kadın & 23 & Bekâr & $\begin{array}{c}12-15 \text { sene } \\
\text { arasinda }\end{array}$ & Lisans & Öğrenci & $1001-2000 \mathrm{TL}$ aras1 \\
\hline 4 & Erkek & 28 & Bekâr & 15 sene ve üzeri & Lisansüstü & Öğrenci & $1001-2000 \mathrm{TL}$ aras1 \\
\hline 5 & Erkek & 23 & Bekâr & 1 seneden az & Lisans & Öğrenci & 1001-2000 TL aras1 \\
\hline 6 & Kadın & 20 & Bekâr & 1-3 sene arasinda & Lisans & Öğrenci & $1001-2000 \mathrm{TL}$ aras1 \\
\hline 7 & Erkek & 25 & Bekâr & 1-3 sene arasinda & Lisans & Öğrenci & $1001-2000 \mathrm{TL}$ aras 1 \\
\hline 8 & Kadın & 24 & Bekâr & 1 seneden az & Lisans & Öğrenci & $1001-2000 \mathrm{TL}$ aras 1 \\
\hline 9 & Kadın & 21 & Bekâr & 1 seneden az & Lisans & Öğrenci & $1001-2000 \mathrm{TL}$ aras 1 \\
\hline 10 & Kadın & 21 & Bekâr & 1 seneden az & Lisans & Öğrenci & $1001-2000 \mathrm{TL}$ aras 1 \\
\hline 11 & Erkek & 32 & Bekâr & 4-7 sene arasinda & Lisansüstü & Akademisyen & $5001-10000 \mathrm{TL}$ aras \\
\hline 12 & Kadın & 24 & Bekâr & 1 seneden az & Lisansüstü & Öğrenci & $1001-2000 \mathrm{TL}$ aras1 \\
\hline 13 & Kadın & 25 & Bekâr & 1 seneden az & Lisansüstü & Öğrenci & $1001-2000 \mathrm{TL}$ ve aras1 \\
\hline 14 & Kadın & 23 & Bekâr & 1-3 sene arasinda & Lisansüstü & Öğrenci & $1001-2000 \mathrm{TL}$ ve aras1 \\
\hline 15 & Kadın & 24 & Bekâr & 1 seneden az & Lisansüstü & Öğrenci & $1001-2000 \mathrm{TL}$ aras1 \\
\hline 16 & Erkek & 23 & Bekâr & 4-7 sene arasinda & Lisans & Öğrenci & $1001-2000 \mathrm{TL}$ aras 1 \\
\hline 17 & Erkek & 18 & Bekâr & 1 seneden az & Lisans & Öğrenci & $1001-2000 \mathrm{TL}$ aras 1 \\
\hline 18 & Erkek & 25 & Bekâr & $1-3$ sene aras 1 & Lisansüstü & Öğrenci & 1001-2000 TL aras1 \\
\hline 19 & Erkek & 45 & Evli & $8-11$ sene aras1 & Lisansüstü & Akademisyen & $5001-10000 \mathrm{TL}$ aras \\
\hline 20 & Erkek & 23 & Bekâr & 1 seneden az & Lisansüstü & Öğrenci & $3001-4000 \mathrm{TL}$ aras1 \\
\hline 21 & Erkek & 22 & Bekâr & 1 seneden az & Lisansüstü & Öğrenci & $3001-4000 \mathrm{TL}$ aras 1 \\
\hline 22 & Erkek & 63 & Evli & 15 sene ve üzeri & Lisansüstü & Akademisyen & $5001-10000 \mathrm{TL}$ aras \\
\hline 23 & Erkek & 18 & Bekâr & 1 seneden az & Lisans & Öğrenci & $1001-2000 \mathrm{TL}$ aras1 \\
\hline 24 & Kadın & 23 & Evli & 1 seneden az & Lisansüstü & Öğrenci & $1001-2000 \mathrm{TL}$ aras 1 \\
\hline 25 & Kadın & 24 & Bekâr & 1 seneden az & Lisans & Öğrenci & $1001-2000 \mathrm{TL}$ aras 1 \\
\hline 26 & Erkek & 25 & Bekâr & $1-3$ sene aras1 & Lisans & Öğrenci & 2001-3000 TL aras1 \\
\hline 27 & Erkek & 24 & Bekâr & 1 seneden az & Lisans & Akademisyen & $5001-10000 \mathrm{TL}$ aras 1 \\
\hline 28 & Kadın & 25 & Evli & 4-7 sene aras1 & Lisansüstü & Akademisyen & $5001-10000 \mathrm{TL}$ aras 1 \\
\hline 29 & Erkek & 26 & Bekâr & 4-7 sene aras1 & Lisansüstü & Akademisyen & $5001-10000 \mathrm{TL}$ aras \\
\hline 30 & Kadın & 34 & Evli & 4-7 sene aras1 & Lisansüstü & Akademisyen & $5001-10000 \mathrm{TL}$ aras \\
\hline
\end{tabular}

Evliyalar şehri olarak da anılan Kastamonu yaklaşık 17 bin evliyanın yaşadığı bir yer olarak dikkat çekmektedir. Anadolu'nun dört manevi direğinden bir olarak tanınan Hz. Pir Şeyh Şaban-1 Veli ve külliyesi (Anadolu'nun diğer üç manevi direği ise; Mevlana Celaleddin Rumi, Hacı Bektaş-1 Veli ve Hacı Bayram-1 Veli'dir) inanç turizmi bağlamında çok büyük ilgi çekmektedir.

Kastamonu ili Karadeniz Bölgesinin batı kesiminde bulunmakta ve birçok turizm türü için önemli bir yerdir. Kitle turizmi, deniz turizmi, yaz turizmi, kongre turizmi, kış turizmi, inanç turizmi, sağlık turizmi, kayak turizmi gibi turizm çeşitlerinde faaliyet gösterilmektedir. Özellikle 2018'de Kastamonu çok önemli gelişme göstermiştir. Bu yılda Türk Dünyası Kültür Başkenti seçilmiştir. Reklam ve tanıtım etkinlikleri çok rağbet görmüştür. Şehir markasında olumlu izler bırakmıştır. Böylelikle şehir ve ülke ekonomisine katkı sağlamış, popülaritesi artmış, ulusal ve uluslararası kanallarda çok büyük yankı bulması sağlanmıştır. Kastamonu 
turizmde önemli bir işleve ve potansiyele sahip bir ildir. Doğa ve tabiatla iç içedir. Yeșilin maviyle buluştuğu olağanüstü bir konuma sahiptir. Şehirdeki altyapı ve üstyap1 gelişim içerisindedir.

Araştırma neticesinde şu öneriler verilmektedir:

- Şehir planlamasına turizm dâhil edilerek gerekli çalışmalar yapılmalıdır.

- Yerel halk ve işletmeciler turizm konusunda bilinçlendirilmelidir. Farkındalık oluşturmak dikkat çekmeyi sağlamaktadır.

- Alternatif turizm uygulamaları piyasaya sunulmalıdır.

- Sağlık turizmi alanında çalışmalar yapmak ve Kastamonu'da bir rehabilitasyon merkezi kurmak şehir açısından önem taşımaktadır.

- Bölgesel kalkınma ajansları tarafından turizme verilen destekler artırılabilir.

- Bölge halkının iletişim kurarken utangaç bir tutum sergilemesi ve çekimser olması turistleri olumsuz etkilemektedir. Bu zorlukların aşılması gerekmektedir.

- Twitter, Youtube, Facebook, Google, Instagram gibi sosyal medya kanallarında, uygulamalarında Kastamonu'daki etkinlikler, festivaller ve çeşitli faaliyetler çok etkileyici, açı, net, istenilen istek ve ihtiyaca tam karşıllı verici bir şekilde tanitilmalidir.

- Kastamonu ilinin çok yönlü web sitesi oluşturmalıdır. Oluşturduğu web sitesinde vizyon ve misyon, amaçları, ürün bilgileri, paydaşları, yapmış olduğu etkinlikler ve planladığı projeler hakkında ayrıntılı bilgiler sunulmalıdır. Bu şekilde yapılan siteler ulaşılmak istenen hedef kitleye karşı olumlu bir tutum oluşturacak, itibar ve güven sağlayacaktır.

\section{Kaynakça}

Avcı, M. (2019). Vuslatının 450. Yıl Dönümünde Hazreti Pir Şeyh Şaban-I Veli (Fikri, Teklifi ve Çabası Serüveni). Kastamonu: Ses Reklam ve Matbaacılık Ltd. Şti.

Baldıran, Ș. ve Ulubay, A. (2008). Turizm Coğrafyası. Ankara: Detay Yayıncılık.

Bardakoğlu, Ö. (2011). Turistik Ürün Bakımından Destinasyon Planlaması Ve Pazarlaması Kapsamında İzmir Turizminin Değerlendirilmesi Ve Geliştirilmesine Yönelik Bir Model Çalışması. Yayınlanmamış Doktora Tezi, Dokuz Eylül Üniversitesi Sosyal Bilimler Enstitüsü.

Bilgin, N. (2000). İçerik Analizi, Ege Üniversitesi Edebiyat Fakültesi Yayınları, İzmir.

Çiftçi, F., (2002). Hazret-i Pir Şeyh Şaban-1 Veli, 3. Baskı, Kastamonu.

Erbaş, A. (2002). İslam Dışı Dinlerde Hac. Sakarya Üniversitesi İlahiyat Dergisi, 5, 97-121.

Güzey, A. R. (2001). Şer'iyye Sicillerine göre XVII. yüzyıl sonları - XVIII. yüzyıl başlarında Kastamonu. Yayınlanmamış Doktora Tezi, Gazi Üniversitesi Sosyal Bilimler Enstitüsü.

İbret, B. Ü., Aydınözü, D. ve Uğurlu, M. (2015). Kastamonu Şehrinde Kültür Ve İnanç Turizmi. Marmara Coğrafya Dergisi, 32, 239-269.

Karabaltaoğlu, Ş. (2019). İnanç Turizmi Destinasyonlarının Yönetimi: Kastamonu Hz. Pir Şeyh Şaban-ı Veli Örneği. Yayınlanmamış Yüksek Lisans Tezi, Kastamonu Üniversitesi Sosyal Bilimler Enstitüsü.

Karacoşkun, M. D. (2004) "Dini İnanç-Dini Davranış İlişkisine Sosyo Psikolojik Yaklaşımlar”, Din Bilimleri Akademik Araştırma Dergisi, Cilt: IV, Sayı: 2, s. 23-35.

Kaynak, İ.H. Ve Sezgin, M. (2008). İnanç Turizmi Kapsamında Dinlerde Seyahat. Selçuk Üniversitesi Sosyal Bilimler Meslek Yüksek Okulu Dergisi. 10(1), 349-359. Http://Dergipark.Ulakbim.Gov.Tr

Kozak, N., Kozak, A. ve Kozak, M. (2010). Genel Turizm Ilkeler-Kavramlar. Ankara: Detay Yayınc1lı. 
Küçük, A, (2010). İnanç Turizmi Açısından Türkiye. Türkiye'de Dinler Tarihi Dünü, Bugünü ve Geleceği, Dinler Tarihi Araştırmaları Dergisi, (VII), 755-789.

Özbay, E., Koç, E., Yapıcı, A., Türkan, A., Baydaş, M. ve Hemiş, İ. (2012). Karşılaştırmalı Dinler Tarihi. Ankara: Milli Eğitim Bakanlığı Yayınları.

Özdemir, G. (2008). Destinasyon Pazarlamast, Ankara, Detay Yayıncılık.

Şenol, F. (2008) Turizm Coğrafyasl, Ankara: Detay Yayıncılık.

Şimşek, H. (2009). "Eğitim Tarihi Araştırmalarında Yöntem Sorunu". Ankara Üniversitesi Eğitim Fakültesi Dergisi, Cilt: 42, Sayı: 1: 33-51.

Tatc1, M., (2012). Hazret-i Pir Şeyh Şaban-ı Veli ve Şabaniyye. İstanbul: H yayınları.

Yakupoğlu, C. (2009). Kuzeybatı Anadolu’nun Sosyo-Ekonomik Tarihi. Ankara: Gazi Kitabevi.

\section{İnternet Kaynakları}

http://arsiv.ntvmsnbc.com/news/442444.asp, Erişim tarihi: 17.04.2019.

https://www.kulturizm.com/region_details.php?Bıd=78, Erişim tarihi: 15.06.2009.

http://www.kastamonukultur.gov.tr/TR63873/inanc-turizmi.html, Erişim tarihi: 17.10.19.

https://kastamonu.ktb.gov.tr/TR-93949/arkeoloji-muzesi.html, Erişim tarihi: 30.11.2019.

https://kastamonu.ktb.gov.tr/TR-93950/etnografya-muzesi.html, Erişim tarihi: 30.11.2019.

https://kastamonu.ktb.gov.tr/TR-93960/nasrullah-kadi-kulliyesi.html, Erişim tarihi: 01.12.2019.

https://kastamonu.ktb.gov.tr/TR-93961/ismailbey-kulliyesi.html, Erişim tarihi: 01.12.2019.

https://kastamonu.ktb.gov.tr/TR-93962/yakupaga-kulliyesi.html, Erişim tarihi: 01.12.2019.

https://kastamonu.ktb.gov.tr/TR-93963/seyh-saban-i-veli-kulliyesi.html, Erişim tarihi: 01.12.2019.

https://kastamonu.ktb.gov.tr/TR-93964/mahmutbey-camii.html, Erişim tarihi: 01.12.2019.

https://kastamonu.ktb.gov.tr/TR-93965/atabeygazi-camii.html, Erişim tarihi: 01.12.2019.

https://kastamonu.ktb.gov.tr/TR-95231/yilanli-camii.html, Erişim tarihi: 01.12.2019. 